\title{
Electronic Conduction and Electrocatalysis by Supramolecular Tetraruthenated Copper Porphyrazine Films
}

\author{
Marcio Y. Matsumoto, Marcos M. Toyama, Ildemar Mayer, Herbert Winnischofer, \\ Koiti Araki and Henrique E. Toma*
}

\author{
Instituto de Química, Universidade de São Paulo, CP 26077, 05513-970 São Paulo-SP, Brazil
}

\begin{abstract}
Uma nova espécie cobre(II)-tetra(3,4-piridil)porfirazina tetrarrutenada, [CuTRPyPz ${ }^{4+}$ foi sintetizada e sua caracterização conduzida por meio de métodos analíticos, espectroscópicos e eletroquímicos. Sua extensa conjugação- $\pi$ a distingue dos derivados análogos da mesotetrapiridilporfirina, levando à ocorrência de interações eletrônicas mais fortes entre os complexos periféricos e o anel porfirazínico central. Com base nas interações eletrostáticas e de empilhamento- $\pi$, foram realizadas montagens, camada-por-camada, de filmes funcionais, combinando-se a [CuTRPyPz $]^{4+}$ com a ftalocianina de cobre(II) tetrassulfonada, [CuTSPc $]^{4-}$. As propriedades condutoras e eletrocatalíticas desses filmes foram investigadas através de técnicas de impedância e de voltametria de disco rotatório, observando-se um comportamento metálico nas proximidades do potencial do par redox $\mathrm{Ru}(\mathrm{III}) /(\mathrm{II})$, bem como uma pronunciada atividade catalítica na oxidação de íons nitrito e sulfito, em meio aquoso.
\end{abstract}

A new tetraruthenated copper(II)-tetra(3,4-pyridyl)porphyrazine species, [CuTRPyPz $]^{4+}$, has been synthesized and fully characterized by means of analytical, spectroscopic and electrochemical techniques. This $\pi$-conjugated system contrasts with the related meso-tetrapyridylporphyrins by exhibiting strong electronic interaction between the coordinated peripheral complexes and the central ring. Based on favorable $\pi$-stacking and electrostatic interactions, layer-by-layer assembled films were successfully generated from the appropriate combination of [CuTRPyPz $]^{4+}$ with copper(II)-tetrasulfonated phtalocyanine, [CuTSPc] $]^{4-}$. Their conducting and electrocatalytic properties were investigated by means of impedance spectroscopy and rotating disc voltammetry, exhibiting metallic behavior near the $\mathrm{Ru}(\mathrm{III} / \mathrm{II})$ redox potential, as well as enhanced catalytic activity for the oxidation of nitrite and sulphite ions.

Keywords: molecular conductors, porphyrazines, ruthenium polypyridines, thin films, electrocatalysis

\section{Introduction}

Phthalocyanines and porphyrins are important macrocyclic compounds exhibiting a wide variety of applications in science and technology. ${ }^{1-13}$ Their main characteristics are associated with the $\pi$-conjugated ring which imparts interesting physical and chemical properties, including the facility of stacking and yielding molecular films. The possibility of rationally manipulating their properties at the nanoscale is a relevant issue to be pursued, aiming the generation of functional molecular materials for nanotechnology devices. ${ }^{14-17}$

*e-mail: henetoma@iq.usp.br
As a matter of fact, tetrapyridyl porphyrins have already been modified with transition metal complexes in order to generate convenient building-blocks and connectors for assembling supramolecular systems and nanostructured materials. ${ }^{18,19}$ In such systems, the transition metal complexes can play many roles, because of their wide variety of structural, electronic, redox and catalytic properties. ${ }^{20-26}$ In particular, the coordination of ruthenium complexes to meso-pyridylporphyrins has provided rather versatile systems, in which the chemical and photochemical reactivity can be modulated by the electronic, structural and steric effects induced by the peripheral complexes. ${ }^{27-32}$ However, it should be noticed that in the case of tetrapyridyl porphyrins, the electronic coupling between the porphyrin center and the ruthenium complexes is mediated by a 
non-coplanar pyridine bridge, reducing to a great extent, their mutual influence in terms of chemical and physical properties. However, a stronger electronic coupling can be expected for coplanar bridged systems such as the tetra(3,4-pyridyl)porphyrazines. In this case, in contrast to the tetrapyridylporphyrins, the bridging pyridyl rings are fused to the macrocycle, becoming part of the $\pi$-extended system. $^{33-35}$

In a previous work, ${ }^{34}$ we have demonstrated that the free-base tetra(3,4-pyridyl)porphyrazine molecule can bind four $\left[\mathrm{Ru}(\mathrm{bpy})_{2} \mathrm{Cl}\right]^{+}$complexes, yielding a stable cationic system. Now, we are focusing on a new tetraruthenated copper(II) tetra(3,4-pyridyl)porphyrazine complex, including an investigation on its interaction with the anionic tetrasulfonated copper(II) phtalocyanine species (Figure 1). It should be noticed that while the preparation of the free-base tetra(3,4-pyridyl)porphyrazine species requires rather complicated synthetic procedures to be accomplished, ${ }^{34}$ the copper(II) derivative is commercially available and provides a more convenient starting material for expanding the investigation on this series of complexes. So, initially, the $[\mathrm{CuTRPyPz}]^{4+}$ complex was synthesized and fully characterized by electrospray ionization mass spectrometry (ESI-MS), UV-Vis spectroelectrochemistry and cyclic voltammetry. Then, layer-by-layer films were electrostatically assembled, and their electrocatalytic activity for nitrite and sulphite oxidation evaluated.

\section{Experimental}

\section{Materials}

The cis-dichloro-bis(2,2'-bipyridine)ruthenium(II) complex, $\left[\mathrm{Ru}\left(\right.\right.$ bpy) $\left.{ }_{2} \mathrm{Cl}_{2}\right]$, was prepared by refluxing $\mathrm{RuCl}_{3} \cdot \mathrm{nH}_{2} \mathrm{O}, \mathrm{LiCl}$ and 2,2'-bipyridine as previously described. ${ }^{34}$ Copper(II) tetra(3,4-pyridyl)porphyrazine, and
copper(II) phtalocyanine tetrasulfonic acid tetrasodium salt was purchased from Aldrich Chemical Co. and used without purification.

The $[\mathrm{CuTRPyPz}]^{4+}$ species was synthesized by refluxing CuTPyPz (100 mg, $0.172 \mathrm{mmol}$ ) and [Ru(bpy) $\left.{ }_{2} \mathrm{Cl}_{2}\right]$ (372 mg, $0.741 \mathrm{mmol}$ ) in trifluoroethanol for $3 \mathrm{~h}$, under an argon atmosphere. After removing the solvent in a flash evaporator, the resulting solid was dissolved in methanol and refluxed again for $3 \mathrm{~h}$. The mixture was filtered and the solvent removed in a rotary evaporator. The solid was washed with acetone and dissolved in a minimum amount of methanol. After adding solid lithium trifluoromethanesulfonate (LiTFMS), the product was precipitated as TFMS salt by adding small amounts of water. Purification was carried out by column chromatography in neutral alumina, starting with a mixture of dichloromethane/ethanol (95:5) and increasing the polarity by the addition of ethanol. Elemental analysis for $\mathrm{Ru}_{4} \mathrm{C}_{112} \mathrm{H}_{76} \mathrm{~N}_{28} \mathrm{O}_{12} \mathrm{~S}_{4} \mathrm{~F}_{12} \mathrm{Cl}_{4} \mathrm{Cu} \cdot 5 \mathrm{H}_{2} \mathrm{O}$ (3062 $\mathrm{g} \mathrm{mol}^{-1}$ ): Exp. (Calc.) C: 43.62 (43.93); H: 2.91 (2.83); N: 12.97 (12.81).

Layer-by-layer electrostatically assembled films were prepared by transferring a precise volume of a methanol solution of [CuTRPyPz]TFMS onto the electrode surface and allowing it to dry in air. After depositing the first layer of the tetracationic species, the electrode was dipped into a [CuTSPc] $]^{4-}$ aqueous solution in order to assemble a bilayered film. ${ }^{36}$ After washing with deionized water, the procedure was repeated, alternating the $[\mathrm{CuTRPyPz}]^{4+}$ and $[\mathrm{CuTSPc}]^{4-}$ solutions for generating multilayered films in a controlled way.

\section{Instrumentation}

UV-Vis spectra were recorded on a HP-8453A diode-array spectrophotometer, in the 190 to $1100 \mathrm{~nm}$ range. Cyclic voltammetry was carried out in

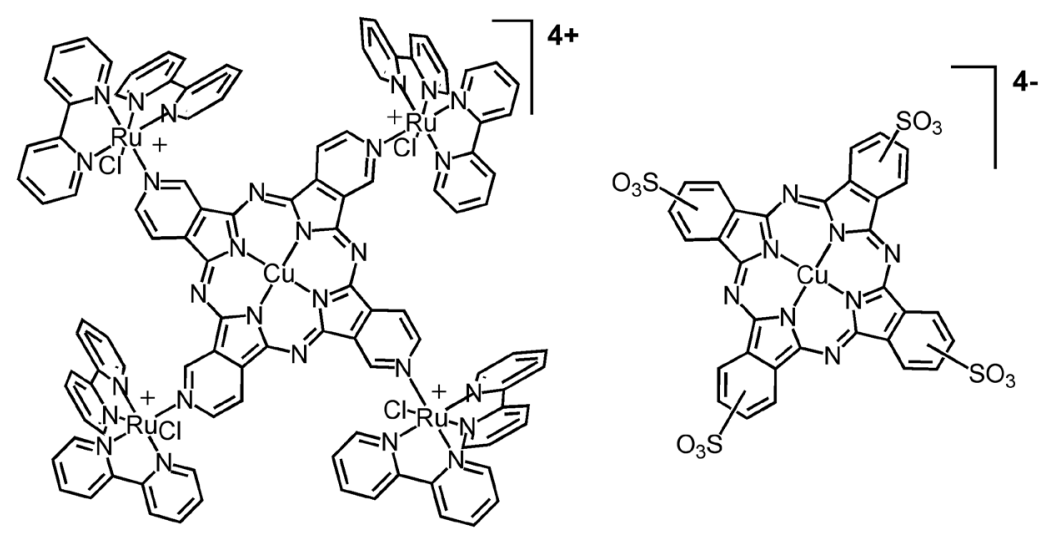

Figure 1. Structural representation of tetraruthenated copper(II)-tetra(3,4-pyridyl) porphyrazine, and tetrasulfonated copper(II)-phthalocyanine used for the preparation of layer-by-layer electrostatic assembled films. 
N,N'-dimethylformamide (DMF), using a Princeton Applied Research model 283 potentiostat. A conventional three electrode cell consisting of a platinum disk working electrode, $\mathrm{Ag} / \mathrm{Ag}^{+}\left(0.010 \mathrm{~mol} \mathrm{dm}{ }^{-3}\right.$, in acetonitrile, $\mathrm{E}^{\circ}=$ $0.503 \mathrm{~V} v$ s. SHE) reference electrode, and a coiled platinum wire auxiliary electrode was employed. The solvents were HPLC grade, but DMF was dried over anhydrous $\mathrm{CuSO}_{4}$ and distilled under vacuum immediately before use. The electrolyte salt $\left[\left(\mathrm{C}_{2} \mathrm{H}_{5}\right)_{4} \mathrm{~N}\right] \mathrm{ClO}_{4}$, or $\mathrm{TEAClO}_{4}$, was purified by recrystallization in water and dried under vacuum. The spectroelectrochemistry data were collected using a previously described homemade thin-layer cell and a PAR model 173 potentiostat/galvanostat in parallel with the HP-8453A spectrophotometer ${ }^{37}$ Electrochemical impedance spectroscopy measurements were carried out with an AUTOLAB PGSTAT30 equipment and a conventional three electrodes electrochemical cell, in the 1 to $10^{5} \mathrm{~Hz}$ range. Electrospray mass spectra were recorded for the samples dissolved in pure methanol, using a Q-Tof (Micromass) mass spectrometer with a quadrupole (Qq) and high-resolution orthogonal time of flight (o-TOF) configuration.

\section{Results and Discussion}

The chemical constitution of the tetraruthenated porphyrazines was confirmed by means of electrospray mass spectrometry. The observed fragmentation pattern can be seen in the global scheme shown in the Figure 2. The $[\text { CuTRPyPz }]^{4+}$ species exhibits the molecular ion peak $\left[\mathrm{C}_{108} \mathrm{H}_{74} \mathrm{~N}_{28} \mathrm{CuRu}_{4} \mathrm{Cl}_{4}\right]^{4+}\left(\mathrm{MM}=2374 \mathrm{~g} \mathrm{~mol}^{-1}\right)$ at $\mathrm{m} / \mathrm{z}$ 594 and $\Delta(\mathrm{m} / z) 0.25$, in the free form, but it also appears as an ion pair, associated with the TFMS ion, at $\mathrm{m} / \mathrm{z}$ $841(\Delta(\mathrm{m} / \mathrm{z})$ 0.33). In the gas phase, the tetraruthenated species is more susceptible to the electrostatic repulsion between the positively charged $\left[\mathrm{Ru}(\mathrm{bpy}){ }_{2} \mathrm{Cl}\right]^{+}$groups, ${ }^{28,38,39}$ undergoing a sequential dissociation of the peripheral complexes. This process generates either the $\left[\mathrm{Ru}(\mathrm{bpy})_{2} \mathrm{Cl}\right]^{+}$ species at $m / z 449$, or the solvated $\left[\mathrm{Ru}(\mathrm{bpy})_{2}\left(\mathrm{CH}_{3} \mathrm{OH}\right) \mathrm{Cl}\right]^{+}$ ones at $\mathrm{m} / \mathrm{z} 481$, as well as the corresponding fragments containing the porphyrazine ring. Doubly and triply charged pyridylporphyrazine bound to two or three $\left[\mathrm{Ru}(\mathrm{bpy})_{2} \mathrm{Cl}\right]^{+}$ complexes have been detected by the characteristic peaks at $\mathrm{m} / \mathrm{z} 642$ and $\mathrm{m} / \mathrm{z} 738$. The monosubstituted species resulting from the loss of three peripheral ruthenium complexes has been observed at $m / z, 1027$.

\section{Electrochemistry and spectroelectrochemistry}

The cyclic voltammograms of [CuTRPyPz $]^{4+}$ exhibit a series of electrochemical waves displaying 1:1 and 1:4 relative intensities, in the -1.5 to $1.7 \mathrm{~V}$ range, as shown in Figure 3. The strong waves at $0.97 \mathrm{~V}$ are characteristic of the reversible $\mathrm{Ru}(\mathrm{III} / \mathrm{II})$ redox couple (wave A).

The spectra of the [CuTRPyPz $]^{4+}$ species in methanol, ethanol or DMF solutions exhibit a complex absorption profile, which can be deconvoluted in terms of a series of bands at 296, 326, 356, 382, 430, 490, 602 and $702 \mathrm{~nm}$, as shown in Figure 4. By comparison with the electronic spectra of similar species, ${ }^{34}$ the peaks at 296, 326 and $490 \mathrm{~nm}$ can be assigned, respectively, as internal $\pi \rightarrow \pi^{*}$ transitions of the bipyridyl ligands, and as $\mathrm{Ru}^{\mathrm{II}} \rightarrow$ bpy $\left(\mathrm{d} \pi \rightarrow \mathrm{p} \pi_{2}^{*}\right)$ and $\left(\mathrm{d} \pi \rightarrow \mathrm{p} \pi_{1}^{*}\right)$ metal-ligand charge transfer transitions (MLCT) in the $\left[\mathrm{Ru}(\mathrm{bpy})_{2} \mathrm{Cl}\right]^{+}$group. The bands at $356,382 \mathrm{~nm}$ can be ascribed to the $\mathrm{B}_{2}$ and $\mathrm{B}_{1}$ Soret bands, and those at $602,702 \mathrm{~nm}$ to the $\mathrm{Q}(0,1)$ and $\mathrm{Q}(0,0)$ bands of CuTPyPz. The $430 \mathrm{~nm}$ is consistent with the MLCT $\mathrm{Ru}^{\mathrm{II}} \rightarrow \mathrm{TPyPz}\left(\mathrm{d} \pi \rightarrow \mathrm{p} \pi^{*}\right)$ transition.

The porphyrazine $\mathrm{Q}$ bands at 602 and $702 \mathrm{~nm}$ exhibit are relatively broad, reflecting the exciton coupling associated with the formation of $\pi$-stacked species. ${ }^{40}$

The corresponding spectroelectrochemical results are shown in Figure 5. The oxidation of the peripheral complexes at $0.97 \mathrm{~V}$ led to the disappearance of the MLCT band at $490 \mathrm{~nm}$, while the broad Q bands at 602 and $706 \mathrm{~nm}$ collapsed into a narrow structured band at $670 \mathrm{~nm}$ (Figure 5A), characteristic of non associated species. This is an interesting result which can be explained considering that the oxidation of the peripheral $\mathrm{Ru}$ (II) complexes to $\mathrm{Ru}(\mathrm{III})$, increases the positive charge on the tetraruthenated species, from +4 to +8 , lowering the probability of occurring $\pi$-stacking interactions. At $1.5 \mathrm{~V}$, a weak, irreversible wave was also detected, suggesting the oxidation of the porphyrazine ring. Unfortunately, spectroelectrochemical measurements at this potential were precluded by the decomposition of the complex.

Four successive reduction reactions were observed in the range of 0.5 to $-1.1 \mathrm{~V}$. According to the corresponding spectroelectrochemical patterns (Figure 5B-E) one can conclude that they do not involve the peripheral ruthenium complexes, since the bipyridyl $\pi \rightarrow \pi^{*}$ band at $293 \mathrm{~nm}$ and the metal-ligand charge transfer band at $490 \mathrm{~nm}$ remained practically unchanged.

The quasi-reversible processes at -0.11 and $-0.50 \mathrm{~V}$ (waves $\mathrm{B}$ and $\mathrm{C}$ ) were ascribed to the first and second monoelectronic reductions of the porphyrazine ring. As a matter of fact, when the potential was changed from 0.50 to $-0.20 \mathrm{~V}$, a decrease in the intensity of the Soret and Q bands at 360 and $710 \mathrm{~nm}$, and an increase of the absorbance at $550 \mathrm{~nm}$ were observed, corresponding to the formation of the porphyrazine radical anion species. When the potentials were changed from -0.20 to $-0.60 \mathrm{~V}$, the intensity 

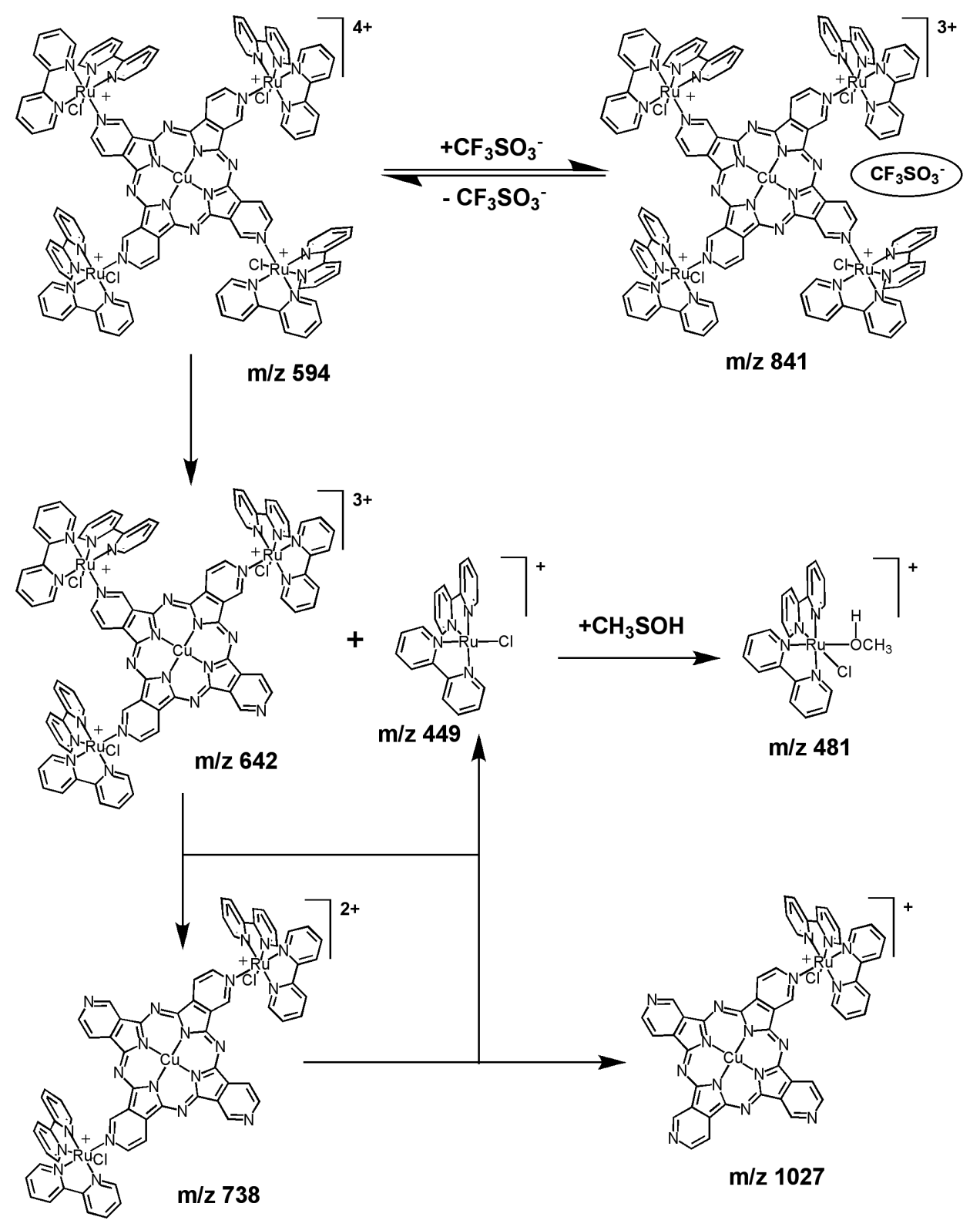

Figure 2. ESI-MS dissociation pattern for the $[\mathrm{CuTRuPyPz}]^{4+}$ complex.

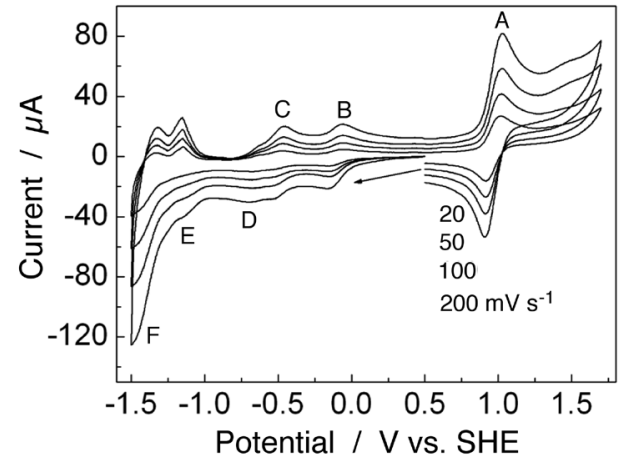

Figure 3. Cyclic voltammograms of the $2.8 \times 10^{-3} \mathrm{~mol} \mathrm{dm}^{-3}[\mathrm{CuTRPyPz}]^{4+}$ in DMF solution containing $0.10 \mathrm{~mol} \mathrm{dm}^{-3}$ of $\mathrm{TEAClO}_{4}$ in 1.7 to $-1.5 \mathrm{~V}$ range, on Pt-disk electrode.

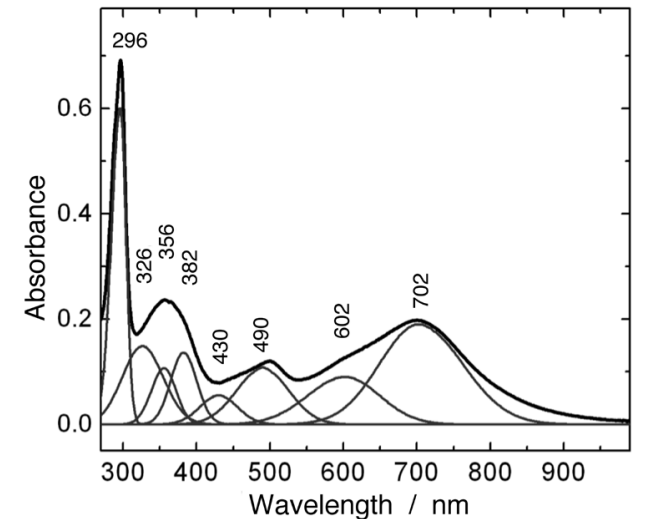

Figure 4. UV-Vis spectrum of $3.4 \times 10^{-6} \mathrm{~mol} \mathrm{dm}^{-3}$ solution of [CuTRPyPz $]^{4+}$ in methanol. 
of the bands attributed to the radical anion decreased and simultaneously a new band rose at $853 \mathrm{~nm}$, consistent with the formation of the porphyrazine dianion.

The third reduction process (wave D) observed in the -0.60 to $-0.80 \mathrm{~V}$ range, led to the decay of the $853 \mathrm{~nm}$ band, and to the increase of absorbance at $525 \mathrm{~nm}$, giving rise to a broad envelope. The fourth reduction process was found in the -0.80 to $-1.20 \mathrm{~V}$ range. In this case, a very broad band appeared at $823 \mathrm{~nm}$ concomitantly with the decrease of the band at $525 \mathrm{~nm}$. These waves are centered at the reduced copper-macrocyclic ring. Considering the previous reduction of the porphyrazine center, the participation of $\mathrm{Cu}(\mathrm{I})$ and $\mathrm{Cu}(0)$ states in the two processes seems very probable.

The last wave, at $-1.39 \mathrm{~V}$, exhibits an intensity comparable to that of the $\mathrm{Ru}(\mathrm{III} / \mathrm{II})$ process, leading to pronounced changes in the $\left[\mathrm{Ru}(\mathrm{bpy})_{2} \mathrm{Cl}\right]^{+}$bands at 293 and $490 \mathrm{~nm}$, supporting the reduction of the bipyridine ligand. The expected 4:1 intensity ratio between the ruthenium complexes and porphyrazine centered electrochemical processes has been observed, and also confirmed by differential pulse voltammetry (DPV) (not shown).

\section{Preparation and electrochemical properties of the supramolecular films}

Tetraruthenated porphyrins and porphyrazines are known to form stable and adherent films on electrodes or substrates like indium tin oxide (ITO) or glassy carbon. ${ }^{33,36,41-43}$ Such molecular films are relatively soluble in conventional solvents, but can be employed in aqueous solution in the presence of a large excess of counter ions, such as $\mathrm{PF}_{6}^{-}$, triflate or perchlorate anions, in order to reduce their solubility. A better approach, however, is by carrying out a layer-by-layer self-assembly, based on a combination with sulphonated porphyrins or phtalocyanines. As a matter of fact, we have observed that the tetraruthenated porphyrazines form highly homogeneous and stable films by electrostatic self-assembly with tetrasulfonated copper(II) phthalocyanines (Figure 1). The buildup of such $[\mathrm{CuTRuPyPz}]^{4+} /[\mathrm{CuTSPc}]^{4-}$ electrostatic assembled bilayered films on ITO can be monitored spectrophotometrically, as shown in Figure 6. There is a steady increase of the absorption bands (inset Figure 6) associated with the ruthenium complexes and the copper(II) porphyrazine and phtalocyanine, as expected for the deposition of equivalent amounts of each species, at each diping process.

In order to investigate the conduction and electrocatalytic properties of the $[\mathrm{CuTRuPyPz}]^{4+} /[\mathrm{CuTSPc}]^{4-}$ films, glassy carbon rotating disk electrodes were used, as shown in Figure 7. The layer-by-layer films exhibited a couple of reversible sine-shaped waves at $0.97 \mathrm{~V}$ related to the oxidation of the peripheral ruthenium ions, i. e. $[\mathrm{Ru}(\mathrm{II}) \rightarrow \mathrm{Ru}(\mathrm{III})]$. This electrochemical process is

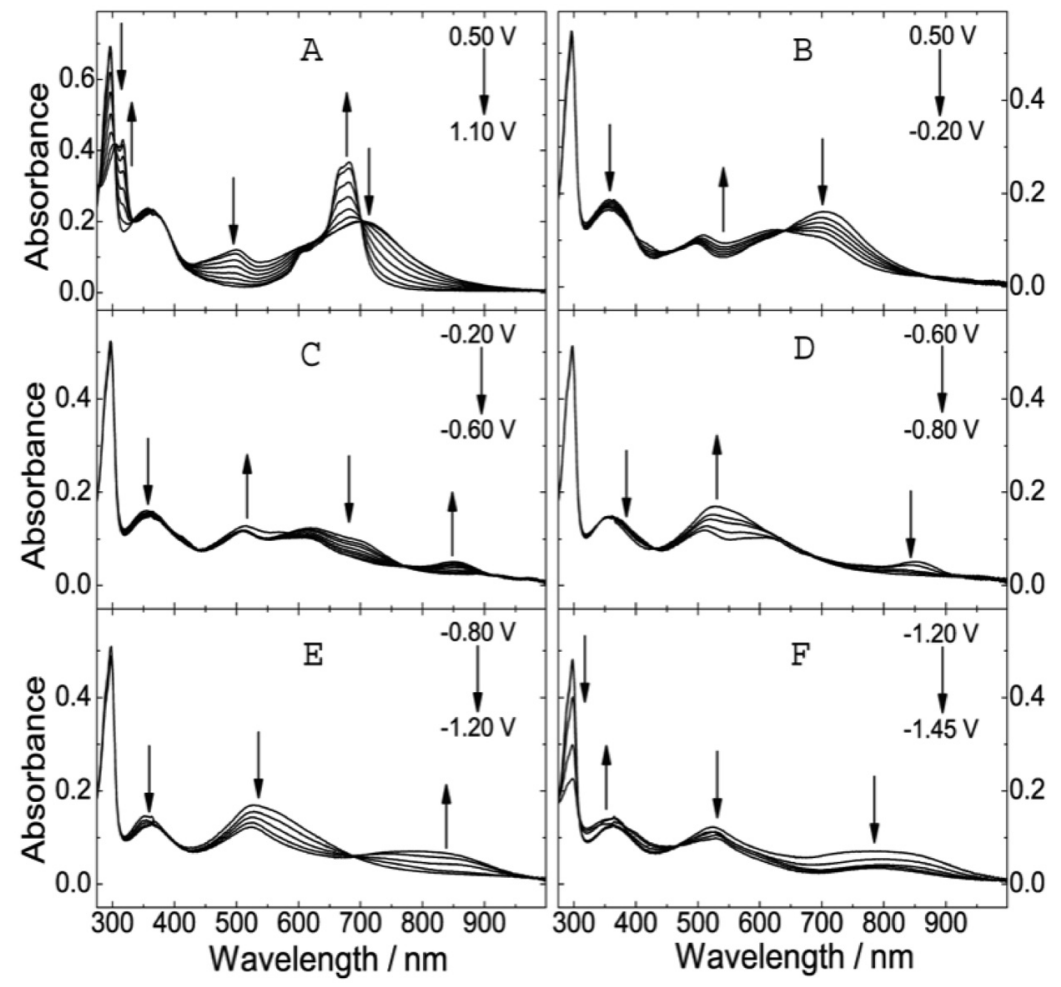

Figure 5. UV-Vis spectroelectrochemistry of a $[\mathrm{CuTRPyPz}]^{4+} 0.10 \mathrm{mmol} \mathrm{dm}^{-3}$ in DMF solution containing $0.10 \mathrm{~mol} \mathrm{dm}^{-3}$ of $\mathrm{TEAClO}_{4}$ in -1.45 to $1.1 \mathrm{~V}$ range. 


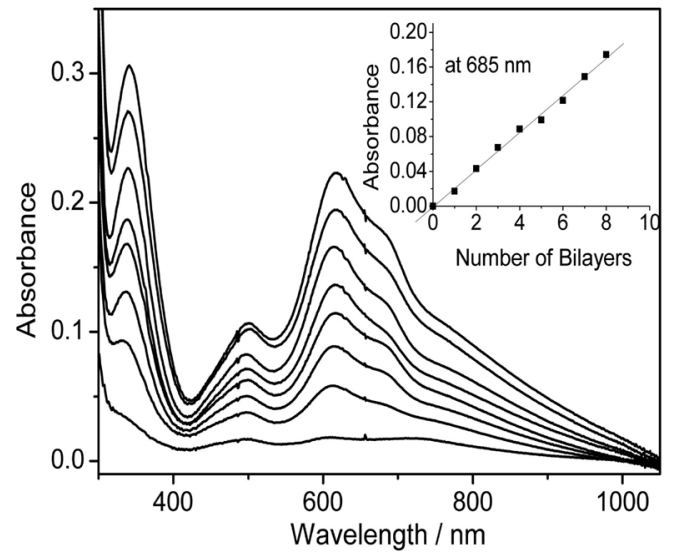

Figure 6. Build-up of layer-by-layer $[\mathrm{CuTRuPyPz}]^{4+} /[\mathrm{CuTSPc}]^{4-}$ films onto ITO glass, monitored by UV-Vis spectroscopy. Inset: plot of absorbance at $685 \mathrm{~nm} v s$. the number of bilayers.

reversible, exhibiting a peak current linearly dependent on the scan rate, as expected when the redox centers are immobilized on the electrode surface.

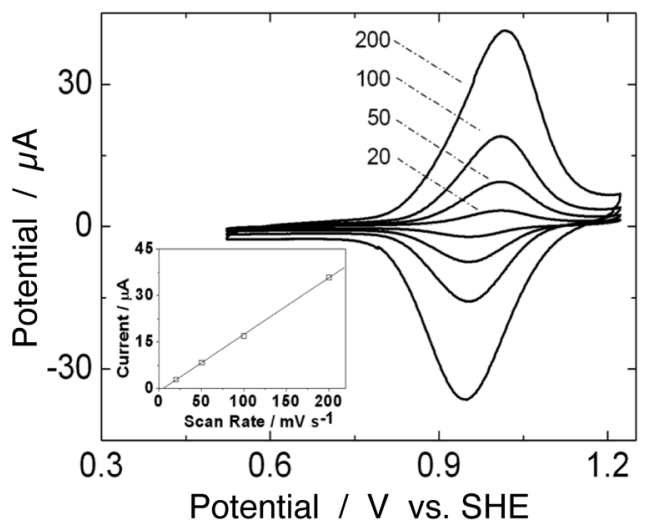

Figure 7. Cyclic voltammograms of a modified glassy carbon electrode containing three $[\mathrm{CuTRuPyPz}]^{4+} /[\mathrm{CuTSPc}]^{4-}$ bilayers, surface coverage $\Gamma=1.86 \times 10^{-10} \mathrm{~mol} \mathrm{~cm}^{-2}$ in $0.5 \mathrm{~mol} \mathrm{dm}^{-3} \mathrm{NaNO}_{3}, \mathrm{pH} 4.5$ aqueous solution. Inset: plot of the peak current intensities as a function of the scan rate.

The conduction properties of the $[\mathrm{CuTRuPyPz}]^{4+/}$ $[\mathrm{CuTSPc}]^{4-}$ films were investigated by means of impedance spectroscopy. The Nyquist plots of the data collected at $0.72 \mathrm{~V}$ and $0.97 \mathrm{~V}$ for $=1.86 \times 10^{-10} \mathrm{~mol} \mathrm{~cm}^{-2}$ are shown in Figure 8. At $0.72 \mathrm{~V}$, there is no significant redox process. In this case, the beginning of a semi-circle can be observed in the high-frequency region, followed by a very short diffusion controlled region and saturation at lower frequencies (inset Figure 8). This kind of response can be analyzed using a simple Randles RC circuit, from which a charge-transfer resistance, $\mathrm{R}_{\mathrm{CT}} c a .60 \Omega$ can be evaluated. The spectrum profile and the $\mathrm{R}_{\mathrm{CT}}$ value are similar to those obtained for analogous free-base tetraruthenated porphyrazine. ${ }^{33}$ On the other hand, the Nyquist plot obtained at $0.97 \mathrm{~V}$, i.e., at $\mathrm{Ru}(\mathrm{III} / \mathrm{II})$ redox potential exhibited a quite different profile as compared with the free-base derivative, in which case an inductive component has been reported. ${ }^{33}$ In the case of the copper(II) derivative no semi-circle associated with activated electron transfer processes nor diffusion controlled Warburg region could be observed, but only a saturation line indicated by a curve nearly perpendicular to the $Z_{R e}$ axis. This indicates that at this potential, the electrode/film/solution interface behaves as a low resistance metallic electronic conductor. Accordingly, the electron hopping between the ruthenium centers should be very fast, at applied potentials near the $\mathrm{E}_{1 / 2}$ of the $\mathrm{Ru}(\mathrm{III} / \mathrm{II})$ redox pair.

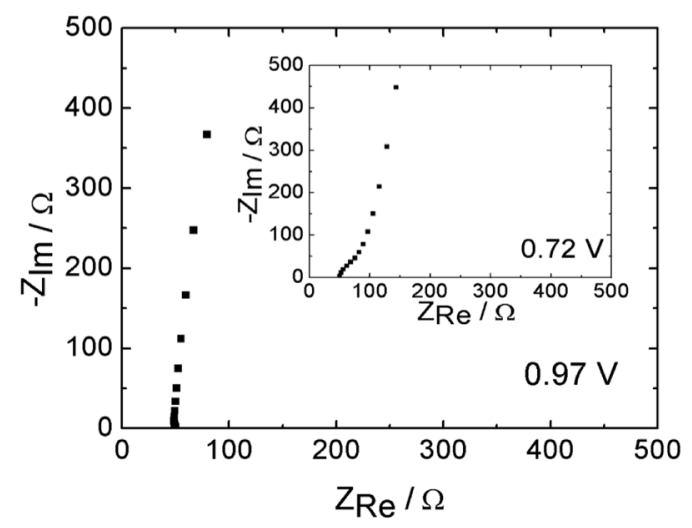

Figure 8. Nyquist plots of the impedance spectroscopy data obtained for a glassy carbon electrode modified with $[\mathrm{CuTRuPyPz}]^{4+} /[\mathrm{CuTSP}]^{4-}$ film $\left(\Gamma=1.86 \times 10^{-10} \mathrm{~mol} \mathrm{~cm}^{-2}\right)$ in $0.5 \mathrm{~mol} \mathrm{dm}^{-3} \mathrm{NaNO}_{3}, \mathrm{pH} 4.5$ aqueous solution, frequencies ranging from $1 \mathrm{~Hz}$ to $100 \mathrm{kHz}$, at $0.97 \mathrm{~V}$ and $0.72 \mathrm{~V}$ (inset).

\section{Electrocatalytic properties of the layer-by-layer films}

Although nitrite and sulfite ions exhibit detectable eletrochemical response in most conventional bare electrodes, the processes are usually irreproducible and severely complicated by electrode poisoning effects. In contrast, when nitrite and sulphite ions are added into the buffered electrolyte solution (Figure 9), the anodic wave at $1.1 \mathrm{~V}$ in the $[\mathrm{CuTRuPyPz}]^{4+} /[\mathrm{CuTSP} c]^{4-}$ films exhibits a large intensification, which increases as a function of the concentration of those species, with no evidence for the corresponding cathodic wave. This observation is consistent with a relatively fast heterogeneous chargetransfer process mediated by the $\mathrm{Ru}(\mathrm{III}) /(\mathrm{II})$ sites, which act as conduction gates, generating an electric rectifying response.

The kinetics of the nitrite to nitrate mediated oxidation reaction were studied by RDE voltammetry in the $100-4000 \mathrm{rpm}$ rotation range. Typical current $v s$. potential curves are shown in Figure $10 \mathrm{~A}$. The voltammograms exhibited a typical sigmoidal shaped profile at low frequencies and concentrations, reaching the limiting currents 


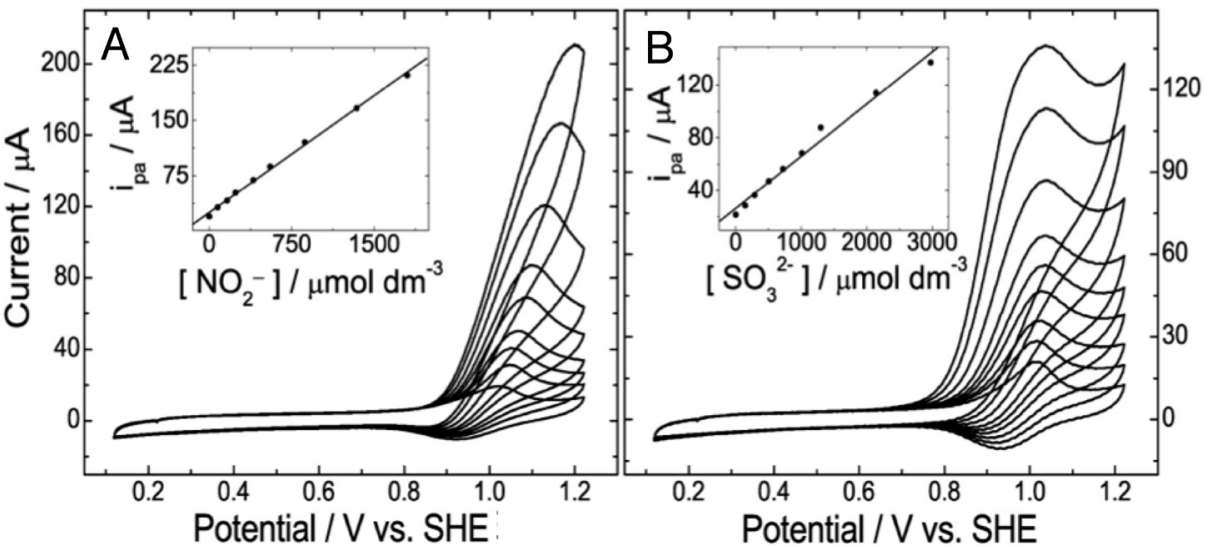

Figure 9. Cyclic voltammograms of glassy carbon electrodes modified with layer-by-layer electrostatic assembled films of $[\mathrm{CuTRuPyPz}]^{4+} /[\mathrm{CuTSPc}]^{4-}$, (A) $\Gamma=0.5 \mathrm{nmol} \mathrm{cm}^{-2}$ and (B) $\Gamma=0.4 \mathrm{nmol} \mathrm{cm}^{-2}$; in the presence of increasing concentration of (A) $\mathrm{NaNO}_{2}$ and (B) $\mathrm{Na}_{2} \mathrm{SO}_{3}\left(0.05\right.$ to $3 \mathrm{mmol} \mathrm{dm}^{-3} \mathrm{range}$ ), in phosphate buffer $\mathrm{pH} 6.8,\left[\mathrm{KNO}_{3}\right]=0.5 \mathrm{~mol} \mathrm{dm}^{-3}$. Inset: Plot of $\mathrm{i}_{\text {pacat }}$ vs. substrate concentration.

at $1.1 \mathrm{~V}$. However, for the determination of the constants, a kinetically limited condition is required. For this reason, the concentration of the substrate was increased up to the point where the Levich plot exhibited a small but increasing curvature as a function of the rotation rate. This is a clear indication that the current is no longer limited by diffusion, but also by the kinetic of the heterogeneous electron-transfer

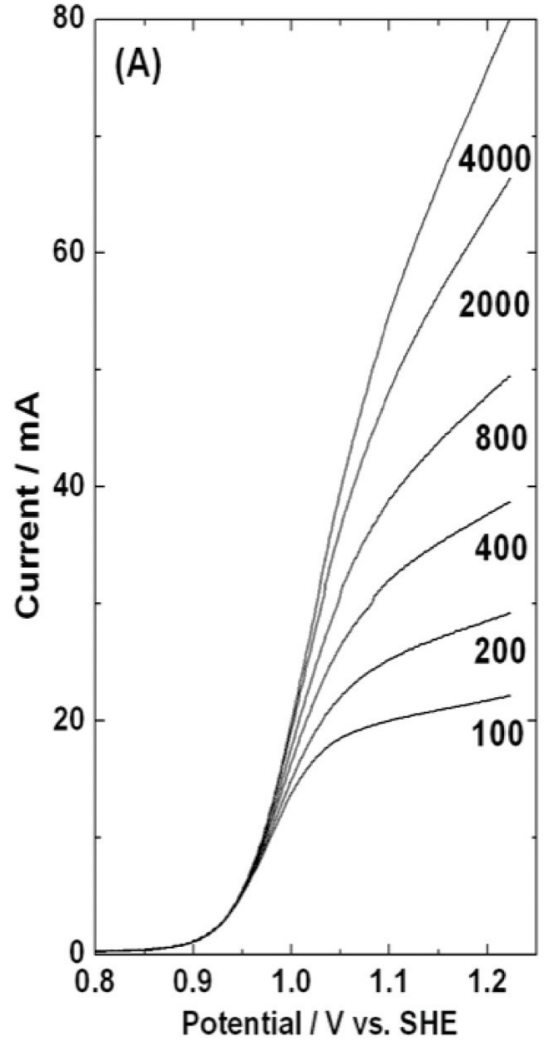

reaction at the film/electrode interface; more specifically, by the reaction between the electrochemically generated mediator $(\mathrm{Ru}(\mathrm{III}))$ and the substrate $\left(\mathrm{NO}_{2}{ }^{-}\right)$in solution. The parameter $\Gamma \mathrm{k}_{\mathrm{f}}=1.45 \times 10^{-2} \mathrm{~cm} \mathrm{~s}^{-1}\left(\Gamma=1.86 \times 10^{-10} \mathrm{~mol} \mathrm{~cm}^{-2}\right)$ was calculated from the linear coefficient of the Koutecky-Levich plots (Figure $10 \mathrm{~B}$ ) as a function of the $\mathrm{NO}_{2}^{-}$concentration (Figure $10 \mathrm{C}$ ).
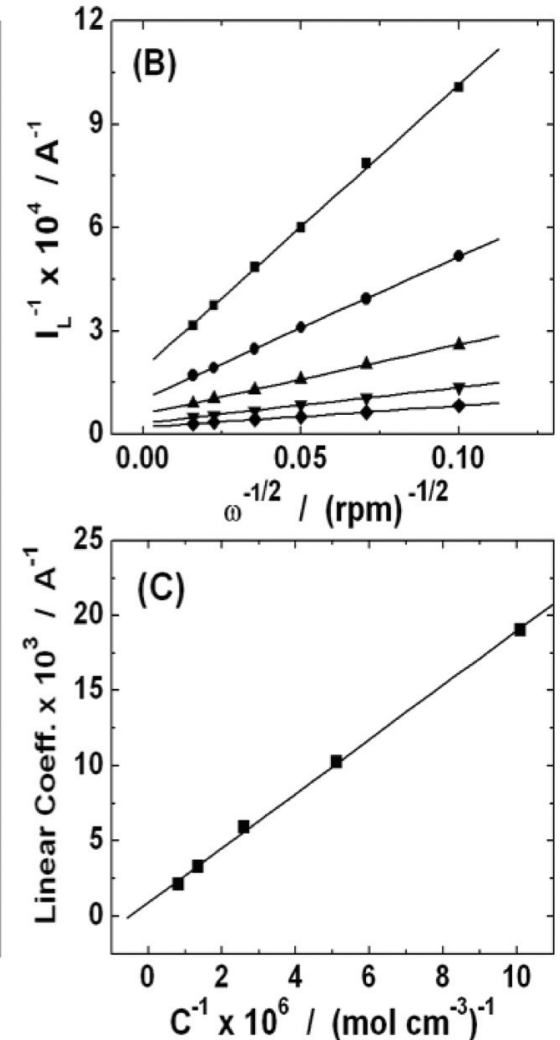

Figure 10. (A) RDE voltammograms of a GC electrode modified with electrostatic assembled films of $[\mathrm{CuTRuPyPz}]^{4+} /[\mathrm{CuTSPc}]^{4-}\left(\Gamma=1.86 \times 10^{-10} \mathrm{~mol} \mathrm{~cm}^{-2}\right)$ in $1.96 \times 10^{-3} \mathrm{~mol} \mathrm{dm}^{-3} \mathrm{NaNO}_{2}$ solution, $\mathrm{NaNO}_{3} 0.5 \mathrm{~mol} \mathrm{dm}^{-3} \mathrm{M}, \mathrm{pH} 4.5$ (acetate buffer), $100<v<4000 \mathrm{rpm}$. (B) Koutecky-Levich plot for RDE experiments using increasing concentrations of nitrite: 0.99 (square), 1.96 (circle), 3.85 (up triangle), 7.41 (down triangle), and $12.3 \times 10^{-4} \mathrm{~mol} \mathrm{dm}^{-3}$ (diamond). The limiting catalytic current was measured at $1.1 \mathrm{~V}$; (C) Plot of linear coefficients of Koutecky-Levich plots vs. reciprocal of nitrite concentration. 
Unfortunately, in the case of the sulfite ions, the kinetics of oxidation mediated by the $[\mathrm{CuTRuPyPz}]^{4+} /[\mathrm{CuTSPc}]^{4-}$ film were too fast to be monitored by RDE, such that the Levich plot was essentially linear up to a concentration of about $10 \mathrm{mmol} \mathrm{dm}^{-3}$ of the substrate, and rotation rate of $5000 \mathrm{rpm}$.

The RDE experiments were also carried out by varying the thickness of the molecular mediator, in order to evaluate the contribution of the surface concentration of the electrocatalytic active sites in the film, and to determine the value of $k_{f}$. Unfortunately, at high surface concentrations, the film resulted too rough, leading to a large dispersion of the $\mathrm{k}_{\mathrm{f}} \Gamma$ results. On the other hand, at very low $\Gamma$, one increases the chances that the electrode surface is not completely covered. For this reason, we selected the intermediate data corresponding to $1.5 \times 10^{-10}<$ $\Gamma / \mathrm{mol} \mathrm{cm}^{-2}<1.5 \times 10^{-9}$ for the determination of $\mathrm{k}_{\mathrm{f}}$ from the slope of $\mathrm{k}_{\mathrm{f}} \Gamma v s$. $\left[\mathrm{NO}_{2}^{-}\right]$plot. As a matter of fact, a linear plot has been obtained, yielding a rate constant $k_{f}=3.3 \times$ $10^{4} \mathrm{~mol} \mathrm{dm}^{-3} \mathrm{~s}^{-1}$. This value is about 10 times higher than that previously obtained for the for self-assembled films based on tetraruthenated cobalt-porphyrin and tetrasulphonated zinc-porphyrin, and it is comparable to the best results yet reported for the films of electropolymerized porphyrins coordinated to four $\left[\mathrm{Ru}(5-\mathrm{ClPhen}){ }_{2} \mathrm{Cl}\right]^{+}$complexes. ${ }^{44,45}$

\section{Conclusions}

The tetraruthenated copper(II)-tetra(3,4-pyridyl) porphyrazine species provides a versatile $\pi$-conjugated system, contrasting with the related meso-tetrapyridylporphyrin analogues by exhibiting strong electronic interaction between the coordinated peripheral complexes and the central ring. The spectrometric, spectroscopic and electrochemical data are in complete agreement with the proposed composition. Electrospray mass experiments revealed an ion-pairing process in the gas phase, and the occurrence of a sequential fragmentation of the peripheral complexes. Layer-by-layer (lbl) electrostatic assembled films were successfully generated by the appropriate combination of $[\mathrm{CuTRuPyPz}]^{4+}$ with copper(II)-tetrasulfonated phtalocyanine, exhibiting metallic conductivity near the $\mathrm{Ru}(\mathrm{III} / \mathrm{II})$ redox potential, as well as enhanced electrocatalytic activity for oxidation of nitrite and sulfite ions.

\section{Acknowledgments}

The authors would like to thank the Fundação de Amparo à Pesquisa do Estado de São Paulo (FAPESP), Conselho Nacional de Desenvolvimento Científico e Tecnológico
(CNPq), and Instituto do Milênio de Materiais Complexos (IMMC) for financial support, and Dr. D. M. Tomazela for her precious help in the mass spectrometry measurements.

\section{References}

1. Kobayashi, N.; Coord. Chem. Rev. 2002, 227, 129.

2. Kobayashi, N.; Coord. Chem. Rev. 2001, 219, 99.

3. Rodriguez-Morgade, M. S.; Stuzhin, P. A.; J. Porphyrins Phthalocyanines 2004, 8, 1129.

4. Salabert, I.; Tranthi, T. H.; Ali, H.; Vanlier, J.; Houde, D.; Keszei, E.; Chem. Phys. Lett. 1994, 223, 313.

5. vanNostrum, C. F.; Nolte, R. J. M.; Chem. Commun. 1996, 21, 2385.

6. Ambroise, A.; Wagner, R. W.; Rao, P. D.; Riggs, J. A.; Hascoat, P.; Diers, J. R.; Seth, J.; Lammi, R. K.; Bocian, D. F.; Holten, D.; Lindsey, J. S.; Chem. Mater. 2001, 13, 1023.

7. Velazquez, C. S.; Fox, G. A.; Broderick, W. E.; Andersen, K. A.; Anderson, O. P.; Barrett, A. G. M.; Hoffman, B. M.; J. Am. Chem. Soc. 1992, 114, 7416.

8. Li, X. Y.; Ng, D. K. P.; Eur. J. Inorg. Chem. 2000, 1845.

9. Kobayashi, N.; Nakajima, S.; Osa, T.; Chem. Lett. 1992 , 2415.

10. Ou, Z. P.; E, W; Shao, J. G.; Burn, P. L.; Sheehan, C. S.; Walton, R.; Kadish, K. M.; Crossley, M. J.; J. Porphyrins Phthalocyanines 2005, 9, 142.

11. Zenkevich, E. I.; von Borczyskowski, C.; Shulga, A. M.; J. Porphyrins Phthalocyanines 2003, 7, 731.

12. Spasojevic, I.; Batinic-Haberle, I.; Inorg. Chim. Acta 2001, 317, 230.

13. Jiang, J. Z.; Liu, W.; Law, W. F.; Ng, D. K. P.; Inorg. Chim. Acta 1998, 268, 49.

14. Love, J. C.; Estroff, L. A.; Kriebel, J. K.; Nuzzo, R. G.; Whitesides, G. M.; Chem. Rev. 2005, 105, 1103.

15. Shen, Z. Y.; Yan, H.; Wang, T.; Seeman, N. C.; J. Am. Chem. Soc. 2004, 126, 1666.

16. Szleifer, I.; Yerushalmi-Rozen, R.; Polymer 2005, 46, 7803.

17. Chau, R.; Brask, J.; Datta, S.; Dewey, G.; Doczy, M.; Doyle, B.; Kavalieros, J.; Jin, B.; Metz, M.; Majumdar, A.; Radosavljevic, M.; Microelectron. Eng. 2005, 80, 1.

18. Toma, H. E.; J. Braz. Chem. Soc. 2003, 14, 845.

19. Toma, H. E.; Current Science 2008, 95, 1202.

20. Manna, J.; Kuehl, C. J.; Whiteford, J. A.; Stang, P. J.; Organometallics 1997, 16, 1897.

21. Drain, C. M.; Goldberg, I.; Sylvain, I.; Falber, A. In Functional Molecular Nanostructures; Schlüter, A. D., ed.; Topics Curr. Chem. 2005, 248, 55.

22. Hofmeier, H.; Andres, P. R.; Hoogenboom, R.; Herdtweck, E.; Schubert, U. S.; Austr. J. Chem. 2004, 57, 419.

23. Milic, T. N.; Chi, N.; Yablon, D. G.; Flynn, G. W.; Batteas, J. D.; Drain, C. M.; Angew. Chem., Int. Ed. 2002, 41, 2117. 
24. Drain, C. M.; Batteas, J. D.; Flynn, G. W.; Milic, T.; Chi, N.; Yablon, D. G.; Sommers, H.; Proc. Natl. Acad. Sci. U. S. A. 2002, 99, 6498.

25. Zimmer, A.; Muller, I.; Reiss, G. J.; Caneschi, A.; Gatteschi, D.; Hegetschweiler, K.; Eur. J. Inorg. Chem. 1998, 2079.

26. Alessio, E.; Macchi, M.; Heath, S. L.; Marzilli, L. G.; Inorg. Chem. 1997, 36, 5614.

27. Nunes, G. S.; Mayer, I.; Toma, H. E.; Araki, K.; J. Catal. 2005 , 236, 55.

28. Mayer, I.; Eberlin, M. N.; Tomazela, D. M.; Toma, H. E.; Araki, K.; J. Braz. Chem. Soc. 2005, 16, 418.

29. Araki, K.; Winnischofer, H.; Viana, H. E. B.; Toyama, M. M.; Engelmann, F. M.; Mayer, I.; Formiga, A. L. B.; Toma, H. E.; J. Electroanal. Chem. 2004, 562, 145.

30. Dovidauskas, S.; Toma, H. E.; Araki, K.; Sacco, H. C.; Iamamoto, Y.; Inorg. Chim. Acta 2000, 305, 206.

31. Winnischofer, H.; Otake, V. Y.; Dovidauskas, S.; Nakamura, M.; Toma, H. E.; Araki, K.; Electrochim. Acta 2004, 49, 3711.

32. Mayer, I.; G. S. Nunes, Toma, H. E.; Araki, K.; Eur. J. Inorg. Chem. 2005, 850.

33. Toyama, M. M.; Demets, G. J. F.; Araki, K.; Toma, H. E.; Electrochem. Commun. 2000, 2, 749.

34. Toyama, M. M.; Franco, M.; Catalani, L. H.; Araki, K.; Toma, H. E.; J. Photochem. Photobiol., A 1998, 118, 11.

35. Toma, H. E.; Araki, K.; Coord. Chem. Rev. 2000, 196, 307.
36. Araki, K.; Wagner, M. J.; Wringhton, M. S.; Langmuir 1996, 12, 5393.

37. Toma, H. E.; Araki, K.; Curr. Org. Chem. 2002, 6, 21.

38. Tomazela, D. M.; Gozzo, F. C.; Mayer, I.; Engelmann, F. M.; Araki, K.; Toma, H. E.; Eberlin, M. N.; J. Mass Spectrom. 2004, 39, 1161.

39. Mayer, I.; Formiga, A. L. B.; Engelmann, F. M.; Winnischofer, H.; Oliveira, P. V.; Tomazela, D. M.; Eberlin, M. N.; Toma, H. E.; Araki, K.; Inorg. Chim. Acta 2005, 358, 2629.

40. Dodsworth, E. S.; Lever, A. B. P.; Seymour, P.; Leznoff, C. C.; J. Phys. Chem. 1985, 89, 5698.

41. AAAraki, K.; Toma, H. E.; Electrochim. Acta 1999, 44, 1577.

42. Araki, K.; Angnes, L.; Toma, H. E.; Adv. Mater. 1995, 7, 554.

43. Azevedo, C. M. N.; Araki, K.; Angnes, L.; Toma, H. E.; Electroanalysis 1998, 10, 467.

44. da Rocha, J. R. C.; Demets, G. J. F.; Bertotti, M.; Araki, K.; Toma, H. E.; J. Electroanal. Chem. 2002, 526, 69.

45. Winnischofer, H.; Lima, S. S.; Araki, K.; Toma, H. E.; Anal. Chim. Acta 2003, 480, 97.

Received: December 7, 2008

Web Release Date: April 30, 2009

FAPESP helped in meeting the publication costs of this article. 